\begin{tabular}{|l|l|l|}
\hline \multicolumn{2}{|c|}{ PublisherInfo } \\
\hline \hline PublisherName & $:$ & BioMed Central \\
\hline \hline PublisherLocation & $:$ & London \\
\hline \hline PublisherImprintName & $:$ & BioMed Central \\
\hline \hline
\end{tabular}

\title{
Genetics and nongenetics of breast cancer
}

\begin{tabular}{|l|l|l||}
\hline \multicolumn{2}{|c|}{ ArticleInfo } \\
\hline \hline ArticleID & $:$ & 4863 \\
\hline \hline ArticleDOI & $:$ & $10.1186 /$ gb-spotlight-20031024-01 \\
\hline \hline ArticleCitationID & $:$ & spotlight-20031024-01 \\
\hline \hline ArticleSequenceNumber & $:$ & 215 \\
\hline \hline ArticleCategory & $:$ & Research news \\
\hline \hline ArticleFirstPage & $:$ & 1 \\
\hline \hline ArticleLastPage & $:$ & 3 \\
\hline \hline & $:$ & RegistrationDate : 2003-10-24 \\
ArticleHistory & $:$ & OnlineDate \\
\hline \hline ArticleCopyright & $:$ & BioMed Central Ltd2003-10-24 \\
\hline \hline ArticleGrants & $:$ & \\
\hline \hline ArticleContext & $:$ & 130594411 \\
\hline \hline
\end{tabular}


Cathy Holding

Email: cholding@hgmp.mrc.ac.uk

Women born with mutations in the $B R C A 1$ and $B R C A 2$ tumor suppressor genes are at greater risk of developing breast and ovarian cancer than the general population, but the level of this has been highly controversial. In the October 24 Science, Mary-Claire King and colleagues at the University of Washington and the New York Breast Cancer Study (NYBCS ) report the genetic analysis of the risk of developing the disease in at-risk women (Science 2003, 302:643-646).

King et al. studied a cohort of breast cancer sufferers in the Ashkenazi Jewish population in New York City by direct genetic analysis of a limited number of known mutations in the index cases and in their relatives. This showed that the lifetime risk for breast cancer in carriers is $82 \%$, and for ovarian cancer, the risk is $54 \%$ for $B R C A 1$ and $23 \%$ for $B R C A 2$ carriers. Low frequency of disease within families did not indicate a lower risk for these family members, and there was a higher risk of developing the disease in women born after 1940, with evidence indicating the involvement of environmental or behavioral factors.

The authors observed that $10.3 \%$ of the 1008 affected women investigated carried an ancient mutation in $B R C A 1$ or $B R C A 2$, similar to the general population, but 52 women were found to be in families with low incidence of disease in which the mutation was inherited from the father. By direct testing of second-, third-, and fourth-degree female relatives, no difference in risk was identified in members of these families compared with other families. Genetic analysis of family members was combined with cancer history to yield the cumulative risk of developing breast or ovarian cancer, and revealed that no difference was associated with specific mutation in breast cancer, but that mutation in $B R C A 1$ gave a greater risk of developing ovarian cancer than $B R C A 2$.

The difference in risk of breast cancer between women born before or after the median birth year of the patients - 1940 - was not due to genetic anticipation and paralleled the increased incidence observed in the general population; no such difference in risk was found for ovarian cancer. Two factors were identified to protect against early onset of breast cancer in this group of women: physical exercise in adolescence and nonobesity at menarche and age 21 .

"Nongenetic factors may significantly influence the penetrance even of high-penetrance mutations. Breast cancer risk in women born before 1940 is high $(\sim 80 \%)$, but risk is even higher for women born after 1940. Identifying these nongenetic influences on penetrance suggests new directions for studies of $B R C A 1$ - and BRCA2-associated carcinogenesis," the authors conclude.

"Results of the NYBCS suggest that the time has come for research studies to examine testing for $B R C A 1 / 2$ mutations in the general population to determine if cancer risks are sufficient to justify general screening," comment Ephrat Levy-Lahad from the Hebrew University of Jerusalem and Sharon Plon at Baylor College of Medicine in an accompanying article (Science 2003, 302:574-575). 


\section{References}

1. New complexities for BRCA1 and BRCA2.

2. Science, [http://www.sciencemag.org/]

3. University of Washington, [http://www.washington.edu/]

4. New York Breast Cancer Study, [http://www.bcrfcure.org/rese_mt_wrds_cur_king.html]

5. Hebrew University of Jerusalem, [http://www.huji.ac.il/unew/main.html]

6. Baylor College of Medicine, [http://www.bcm.tmc.edu/] 